\title{
Draft genome sequence of Staphylococcus sp. EZ-P03 isolated from a mesophilic anaerobic digester
}

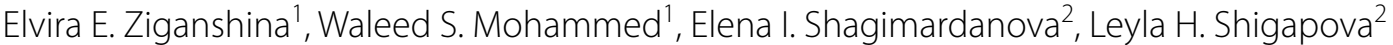 \\ and Ayrat M. Ziganshin ${ }^{1 *}$ (D)
}

\begin{abstract}
Objectives: Staphylococcus species of the family Staphylococcaceae are facultatively anaerobic Gram-positive cocci growing in clusters, pairs and occasionally in short chains. Staphylococci can be detected in different environments. They are common commensals, but some can also cause infections in humans. Hence, their investigation is required to understand ecology and genetics and to create an opportunity for comparative studies.
\end{abstract}

Data description: In this study, we report the determination of a draft genome sequence of Staphylococcus sp. strain EZ-P03 which was isolated from anaerobically digested chicken waste materials. The draft genome of Staphylococcus sp. EZ-P03 constituted a total of 62 contigs (> $500 \mathrm{bp}$ ) amounting to 2,689,358 bp with a $\mathrm{G}+\mathrm{C}$ content of $37.3 \%$ and a N50 contig size of 126,562 bp. The whole genome shotgun project of Staphylococcus sp. strain EZ-P03 has been deposited at DDBJ/ENA/GenBank under the accession number QPMO00000000.

Keywords: Draft genome, Firmicutes, Staphylococcus sp., Chicken manure, Laboratory-scale mesophilic reactor

\section{Objective}

Staphylococcus species of the family Staphylococcaceae are facultatively anaerobic Gram-positive cocci growing in clusters, pairs and occasionally in short chains. Staphylococci grow by respiration or fermentation and can be found in different environmental niches. S. aureus and $S$. epidermidis species are common commensals but have a high pathogenic potential. S. saprophyticus, S. haemolyticus, S. simulans, S. cohnii, S. warneri and others can also cause infections in human $[1,2]$. Some Staphylococcus species with proteolytic activities have been shown to survive in various anaerobic digesters $[3,4]$. The anaerobic digestion process is an appropriate technology for different agricultural wastes utilization $[5,6]$; however, it is also important to develop effective hygiene and sanitation procedures to minimize the potential disease

\footnotetext{
*Correspondence: ayrat.ziganshin@kpfu.ru

${ }^{1}$ Department of Microbiology, Institute of Fundamental Medicine and Biology Kazan (Volga Region), Federal University, Kremlyovskaya STR. 18, Kazan 420008, Russia

Full list of author information is available at the end of the article
}

transfer risk [7, 8]. Genome analysis of species belonging to the genus Staphylococcus is required to understand their ecology and genetics and to create an opportunity for comparative studies.

\section{Data description}

Staphylococcus sp. EZ-P03 was isolated from a mesophilic anaerobic digester operated at high ammonia levels $\left(>6.0 \mathrm{NH}_{4}-\mathrm{N} \mathrm{g} \mathrm{L}^{-1}\right)$ and fed with chicken manure as monosubstrate [4]. The strain Staphylococcus sp. EZ-P03 was cultured at $+37^{\circ} \mathrm{C}$ on Luria agar for $48 \mathrm{~h}$ under microaerophilic conditions. Genomic DNA from the bacterial cells (washed with sterile phosphate buffer solution) was extracted with the FastDNA spin kit (\#116540600; MP Biomedicals). DNA quantification and quality control were performed by agarose gel electrophoresis and measurement with a NanoDrop 2000 spectrophotometer (\#ND-2000; Thermo Fisher Scientific) confirming an optical density $260 / 280$ of between 1.8 and 2 and finally stored at $-20{ }^{\circ} \mathrm{C}$. The bacterial strain EZ-P03 was initially identified based on morphological, 
Table 1 Overview of data files/data sets

\begin{tabular}{llll}
\hline Label & Name of data file/data set & File types (file extension) & $\begin{array}{l}\text { Data repository and identifier (DOI } \\
\text { or accession number) }\end{array}$ \\
\hline Data file 1 & Whole genome shotgun project & FASTA & GenBank accession (QPMO00000000) \\
Data file 2 & 16S rRNA gene sequence & FASTA & GenBank accession (MH651712) \\
\hline
\end{tabular}

biochemical and growth characteristics and finally confirmed by sequencing of the $16 \mathrm{~S}$ rRNA gene (Table 1) (16S rRNA gene sequence, $1404 \mathrm{bp}$, BLAST identity of 99\% to S. simulans and 98\% to S. piscifermentans, S. condiment and S. carnosus).

The paired-end DNA libraries were prepared as described previously by us [9] as well as in accordance with the Illumina protocol. DNA fragmentation and DNA library preparation were checked with a High Sensitivity DNA kit (\#5067-4626; Agilent) and a 2100 Bioanalyzer (\#G2939BA; Agilent). Genome sequencing was fulfilled with an Illumina MiSeq platform (\#SY-410-1003; Illumina) at Joint KFU-Riken Laboratory, Kazan (Volga Region) Federal University (Kazan, Russia) as detailed previously [9]. A quality of the sequence data was analyzed with the FastQC software [10], the genome was assembled with the algorithm package Velvet, version 1.2.10 [11], and the arrangement of contigs was then achieved with the Mauve program, version 2.4.0 [12]. Rapid Annotation System Technology (RAST) server (annotation scheme: RASTtk) was used to annotate the whole genome sequence of Staphylococcus sp. strain EZ-P03 [13]. The rRNA and tRNA genes were predicted with the RNAmmer 1.2 [14] and tRNA scan-SE 1.23 [15], accordingly. PlasmidFinder-1.3 Server was used to identify plasmids in the sequenced strain [16]. Comparison of the genomic feature of Staphylococcus sp. strain EZ-P03 with some other Staphylococcus species was fulfilled with the data received from an integrated database EzBioCloud [17]. Finally, the strain was identified as Staphylococcus sp. belonging to the family Staphylococcaceae within the phylum Firmicutes.

The draft genome of Staphylococcus sp. strain EZ-P03 constituted a total of 62 contigs ( $>500 \mathrm{bp}$ ) amounting to $2,689,358$ bp with a $\mathrm{G}+\mathrm{C}$ content of $37.3 \%$ and a N50 contig size of $126,562 \mathrm{bp}$. Two plasmid sequences were also identified in the strain EZ-P03 (3018 bp and $1111 \mathrm{bp}$ ). RAST server predicted 2571 coding sequences. The genome of Staphylococcus sp. strain EZ-P03 was shown to encode at least 68 RNAs, including 8 rRNAs and 60 tRNAs. The strain Staphylococcus sp. EZ-P03 has several genes responsible for saccharides and proteins degradation, mixed acid and lactate fermentation, as well as urea decomposition. Moreover, several genes responsible for resistance to antibiotics (such as fluoroquinolones) and toxic compounds, including mercury, arsenic, cadmium and chromium compounds, were observed.

\section{Limitations}

The exact length of the genome, synteny, number of rRNA genes and repetitive elements cannot be reported since the obtained data is based on the draft level genome sequence.

\section{Authors' contributions}

WSM and EEZ conducted experiments, fulfilled genome analysis and interpretation of the data. EIS and LHS performed Illumina sequencing. AMZ supervised the project, designed the study and wrote the manuscript. All authors read and approved the final manuscript.

\section{Author details \\ ${ }^{1}$ Department of Microbiology, Institute of Fundamental Medicine and Biol- ogy Kazan (Volga Region), Federal University, Kremlyovskaya STR. 18, Kazan 420008, Russia. ${ }^{2}$ Laboratory of Extreme Biology, Institute of Fun- damental Medicine and Biology Kazan (Volga Region), Federal University, Kazan 420021, Russia.}

Acknowledgements

Not applicable.

\section{Competing interests}

The authors declare that they have no competing interests.

\section{Availability of data materials}

The data described in this Data note can be freely and openly accessed at DDBJ/ENA/GenBank. Accession Numbers-QPMO00000000 (whole genome project) [18] and MH651712 (16S rRNA gene sequence) [19].

\section{Consent for publication}

Not applicable.

\section{Ethics approval and consent to participate}

Not applicable.

\section{Funding}

This study was funded by the Russian Foundation for Basic Research [Grant No. 16-34-60093 mol_a_dk]. Additional support was provided by the grant of the President of the Russian Federation for the young scientists [Grant No. МД-100.2017.4]

\section{Publisher's Note}

Springer Nature remains neutral with regard to jurisdictional claims in published maps and institutional affiliations.

Received: 30 July 2018 Accepted: 20 September 2018

Published online: 03 October 2018 


\section{References}

1. Foster T. Staphylococcus. In: Baron S, editor. Medical microbiology. 4th ed. Galveston: University of Texas Medical Branch at Galveston; 1996.

2. Humphreys H. Staphylococcus: skin infections; osteomyelitis; bloodstream infection; food poisoning; foreign body infections; MRSA. In: Medical Microbiology, 8th Edn. 2012. p. 176-82

3. Wirth R, Kovács E, Maróti G, Bagi Z, Rákhely G, Kovács KL. Characterization of a biogas-producing microbial community by short-read next generation DNA sequencing. Biotechnol Biofuels. 2012;5:41.

4. Ziganshina EE, Ibragimov EM, Vankov PY, Miluykov VA, Ziganshin AM. Comparison of anaerobic digestion strategies of nitrogen-rich substrates: performance of anaerobic reactors and microbial community diversity. Waste Manag. 2017;59:160-71.

5. Horváth IS, Tabatabaei M, Karimi K, Kumar R. Recent updates on biogas production-a review. Biofuel Res J. 2016;10:394-402.

6. Ziganshin AM, Ziganshina EE, Kleinsteuber S, Nikolausz M. Comparative analysis of methanogenic communities in different laboratory-scale anaerobic digesters. Archaea. 2016:2016:3401272.

7. Colleran E. Hygienic and sanitation requirements in BGPs treating animal manures or mixtures of manures and other organic wastes. In: Ortenblad $\mathrm{H}$, editor. Anaerobic digestion: making energy and solving modern waste problems; 2000. p. 77-86.

8. Sahlström L. A review of survival of pathogenic bacteria in organic waste used in biogas plants. Bioresour Technol. 2003;87:161-6.

9. Ziganshina EE, Mohammed WS, Doijad SP, Shagimardanova El, Gogoleva $N E$, Ziganshin AM. Draft genome sequence of Brevibacterium epidermidis EZ-K02 isolated from nitrocellulose-contaminated wastewater environments. Data Brief. 2018;17:119-23.

10. Bioinformatics Babraham. FastQC: a quality control tool for high throughput sequence data. Cambridge: Babraham Institute; 2011
11. Zerbino DR. Using the Velvet de novo assembler for short-read sequencing technologies. Curr Protoc Bioinform. 2010;11(11):5.

12. Rissman Al, Mau B, Biehl BS, Darling AE, Glasner JD, Perna NT. Reordering contigs of draft genomes using the Mauve aligner. Bioinformatics. 2009:25:2071-3.

13. Aziz RK, Bartels D, Best AA, DeJongh M, Disz T, Edwards RA, et al. The RAST server: rapid annotations using subsystems technology. BMC Genomics. 2008;9:75.

14. Lagesen K, Hallin P, Rødland EA, Staerfeldt HH, Rognes T, Ussery DW. RNAmmer: consistent and rapid annotation of ribosomal RNA genes. Nucleic Acids Res. 2007:35:3100-8.

15. Lowe TM, Eddy SR. tRNA scan-SE: a program for improved detection of transfer RNA genes in genomic sequence. Nucleic Acids Res. 1997;25:955-64.

16. Carattoli A, Zankari E, García-Fernández A, Voldby Larsen M, Lund O, Villa L, Møller Aarestrup F, Hasman H. In silico detection and typing of plasmids using PlasmidFinder and plasmid multilocus sequence typing. Antimicrob Agents Chemother. 2014:58:3895-903.

17. Yoon SH, Ha SM, Kwon S, Lim J, Kim Y, Seo H, Chun J. Introducing EzBioCloud: a taxonomically united database of $16 \mathrm{~S}$ rRNA and whole genome assemblies. Int J Syst Evol Microbiol. 2017;67:1613-7.

18. Ziganshina EE, Mohammed WS, Shagimardanova El, Shigapova LH, Ziganshin AM. Staphylococcus sp. EZ-P03, whole genome shotgun sequencing project. Genbank QPMO00000000. 2018. https://www.ncbi. nlm.nih.gov/nuccore/QPMO00000000.1/.

19. Ziganshina EE, Mohammed WS, Shagimardanova El, Shigapova LH, Ziganshin AM. Staphylococcus sp. strain EZ-P03 16S ribosomal RNA gene, partial sequence. Genbank MH651712. 2018. https://www.ncbi.nlm.nih. gov/nuccore/MH651712
Ready to submit your research? Choose BMC and benefit from:

- fast, convenient online submission

- thorough peer review by experienced researchers in your field

- rapid publication on acceptance

- support for research data, including large and complex data types

- gold Open Access which fosters wider collaboration and increased citations

- maximum visibility for your research: over $100 \mathrm{M}$ website views per year

At $\mathrm{BMC}$, research is always in progress.

Learn more biomedcentral.com/submissions 